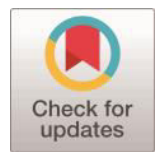

Article Type: Research Paper

\section{Analysis of the Effect of Unemployment Rate, RMW, and HDI on Poverty Rates in the Special Region of Yogyakarta}

\author{
Yolanda Oktaviani* \& Indanazulfa Qurrota A'yun
}

Abstract: Poverty is one of the most complex problems in a country's economy, including in a region. Therefore, efforts to reduce poverty must be carried out comprehensively. The purpose of this study was to analyze the effect of the unemployment rate, the Regional Minimum Wage (RMW), and the Human Development Index (IPM) on the poverty rate in the districts of Bantul, Sleman, Gunung Kidul, Kulon Progo, and the City of Yogyakarta in 2015-2019. The analytical method used is panel data regression random effect models (REM). This study indicates that the unemployment rate, regional minimum wage, and HDI simultaneously affect the poverty level. Partially, the unemployment rate is positively and not significantly correlated with the poverty rate.

Keywords: Unemployment Rate; RMW; HDI; Poverty Rate; DIY

JEL Classification: 015; E24; 132

\section{Introduction}

Poverty is one of the most complex problems in the economy of a country, including the region. Because it is multidimensional, the handling of poverty is not enough to be seen from one side only. Economic aspects, social aspects, and even cultural aspects can affect poverty in an area.

A world economist, Adam Smith, once stated that no society is prosperous and happy if most of its population is in poverty and misery. In line with this opinion, people's poverty is one of the domino effects of poverty. Poverty makes a person unable to access various services needed in his life correctly. As a result, people cannot live properly.

Poverty is also been a big problem throughout Indonesia's history. There is no more significant problem than poverty in a country, including Indonesia (Prawoto, 2008). According to the Central Bureau of Statistics (BPS) data, the number of poor people in Indonesia in September 2020 was 27.55 million people or 10.19 percent, an increase of 0.41 percent from March 2020 and 0.92 percent from September 2019.

Poverty is still a significant problem in various regions in Indonesia, including the Special Region of Yogyakarta (DIY). As a result, local governments compete with each other to develop poverty alleviation programs. 
Programs that have been launched include subsidies, social assistance funds, job training, educational scholarships, and many others-all of these program's aim is reducing poverty levels in both the short and long term.

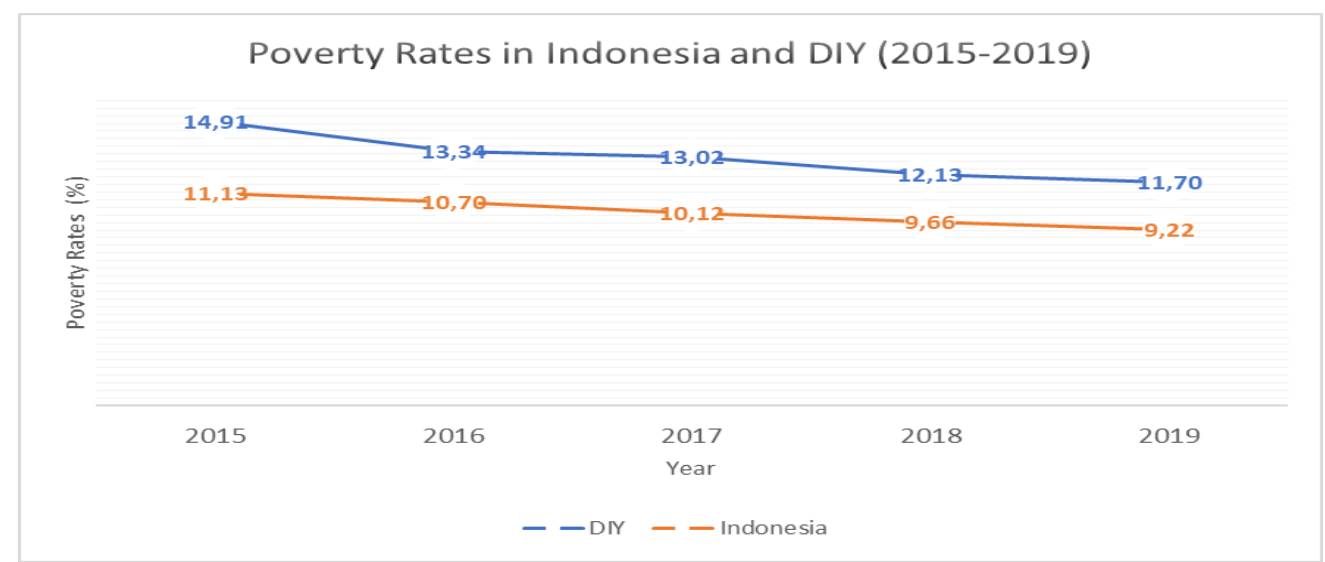

Figure 1 Poverty Rates in Indonesia and DIY in 2015-2019

Source: BPS 2020

The Special Region of Yogyakarta (DIY) is unique when it comes to discussing poverty. Although it is known as the City of Students and has a relatively high Human Development Index (HDI), the poverty rate of DIY has always been higher than the national poverty rate for the last five years. The DIY unemployment rate is also relatively much lower than the national unemployment rate. It is, of course, a particular concern why the poverty rate in DIY, even in several districts such as Bantul, Gunung Kidul, and Kulon Progo value is much higher than the national poverty rate.

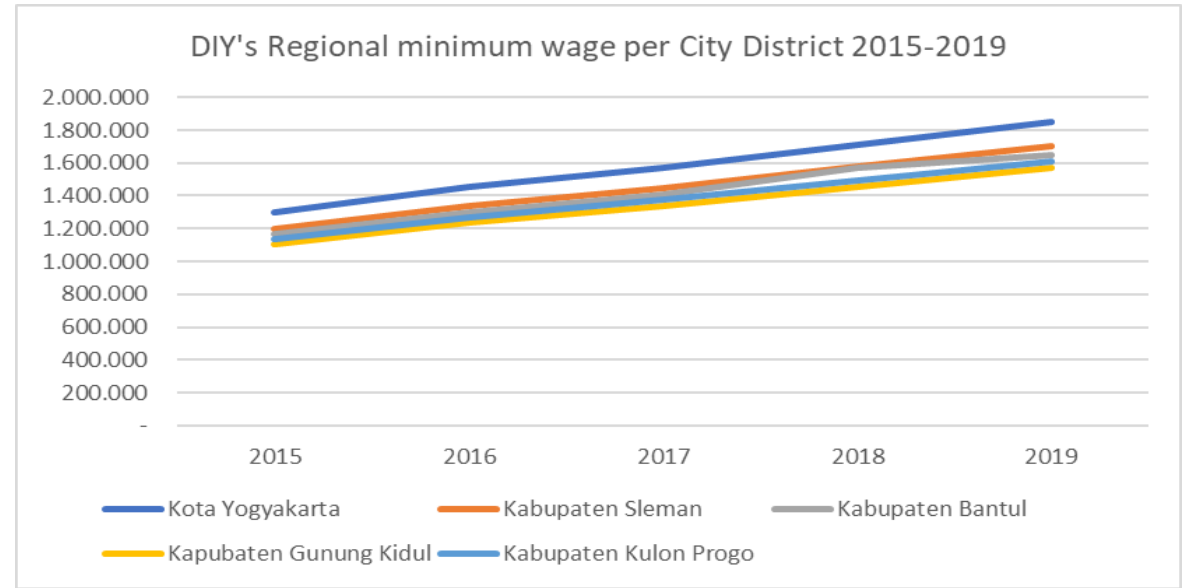

Figure 2 DIY's Regional Minimum Wage per City District 2015-2019 Source: BPS 2020

As previously mentioned, the government has made various efforts, including the DIY Government, in overcoming this poverty problem. In addition to those already mentioned, one of the efforts is increasing the regional minimum wage (RMW). This increase in wages is expected to improve the standard of living of the community. For 
the last five years, all regencies and cities in DIY have increased their minimum wage. In several studies, it stated that the minimum wage has a significant influence on the poverty level. For this reason, this paper tries to prove whether this influence also applies to the poverty rate in DIY. In addition to using the RMW the same as the previous study, two other variables were added, namely the unemployment rate and the Human Development Index (HDI), to complement existing research.

Development is a process that aims to improve the population's welfare in the region, where the measure of welfare can be seen from the decrease in poverty levels and the distribution of income of the population. That means that the poverty level is a measure of the welfare of the population. The higher the poverty level, the lower the welfare level and vice versa (Probosiwi, 2016). Poverty is also described by less income in meeting minimum living needs such as clothing, food, housing, education, and health (Amins, 2017).

Poverty has several impacts, one of which is unemployment. Unemployment harms prosperity, national income and increases state spending (Itang, 2017). Unemployment is a situation without work faced by a group of workers who have tried to find work but did not get it (Sukirno, 2006).

Thus, there is a relationship between unemployment and poverty. Furthermore, according to Munandar and Mahmuddin (2019) research, the poverty rate will decrease if unemployment decreases. Thus, there is a positive and significant relationship between the unemployment rate and changes in the poverty level in the long term, namely the lower the unemployment rate, the better the poverty level.

In addition, the regional minimum wage also affects the poverty level. Riva et al. (2014), in his research, explains that the provincial minimum wage level has a positive influence on poverty. The minimum wage influences poverty due to the social cost of inflation which makes a person poorer. The minimum wage does not depend on the magnitude of inflation and does not make workers' wages rise. Instead, inflation makes product prices rise, and workers' minimum wage becomes smaller (Waluyo, 2007).

Not only the minimum wage, but Subandi (2012) also explained that one of the efforts to alleviate poverty is building human resources. It can be done by improving social services such as education, health, and nutrition. The government makes this effort to improve welfare and reducing poverty. Human resource development is usually measured by the Human Development Index (HDI) or the Human Development Index (IPM), an index to measure the quality of human development.

Todaro and Smith (2006) explains that the HDI is an index of human development seen through the mapping, expansion, and equity aspects in health, education, and community welfare. Low HDI levels will have an impact on low productivity levels. Low productivity results in low income. Low income will lead to an increase in the number of poor people. 


\section{Oktaviani \& A'yun}

Analysis of the Effect of Unemployment Rate, RMW, and HDI ...

Several studies have proven that HDI affects poverty levels. For example, in the research of Sofilda et al. (2013), it was shown that HDI had a negative and significant effect on poverty in the Regency/City of Papua Province. Likewise, Suliswanto (2010) research conducted that HDI plays a crucial role in tackling poverty levels in Indonesia. In the latest research conducted by Suripto and Subayil (2020), it is explained that HDI affects poverty levels, so it is necessary to increase HDI by improving the quality of human resources in the fields of education, health and supporting improvements in other fields. In other words, people's welfare will be better, and poor people will decrease. Thus, this paper stands in filling the explanation of that relationship in Yogyakarta.

\section{Research Method}

A research method is a scientific method or process to obtain data with specific uses and purposes. In this study, the author uses a descriptive cross-sectional method to determine whether there is a relationship between the independent and dependent variables from the regression test using previous data. In this case, the data used are secondary data obtained from related sources, in this case, the Central Bureau of Statistics (BPS) and the Yogyakarta Regional Development Planning Agency (BAPPEDA). The poverty, unemployment, RMW, and HDI levels are presented in a systematic and actual graph. The data were analyzed using a random effect model regression technique with the STATA 16.0 program.

Multiple regression analysis can describe the schema of the relationship between poverty and the variables that influence it. We use multiple regression analysis in this study to determine the effect of the independent variables, namely the unemployment rate, RMW, and $\mathrm{HDI}$, on the dependent variable, namely the poverty level. The regression equations in this study, namely:

$$
Y^{\prime}=\alpha+1 X 1+2 X 2+3 X 3+\varepsilon
$$

Information: $\left(Y^{\prime}\right)=$ Poverty Rate. $(\alpha)=$ constant. $(\beta)=$ regression coefficient. $(X 1)=$ Unemployment Rate. $(X 2)=$ regional minimum wage. $(X 3)=$ HDI.

After the Heteroscedasticity and Multicollinearity test, the data passed the test and could be used. In addition, the time series and cross-section also do not interfere with the model. It can be proven from the testparm test and the Pesaran test, which produces more than 0.05 .

\section{Result and Discussion}

\section{Analysis results}

The data was processed using a random effect regression model. This model was chosen based on the Lagrangian Multiplier test that has been carried out. The probability value 
of 0.000 indicates that the random-effects model is better than OLS. Based on the results of data processing using the random effect model method, the following results were obtained:

R-sq : 0.886

Prob > chi2 : 0.000

Table 1 The Result of Estimation

\begin{tabular}{cccc}
\hline Variable & Coef. & $Z$ & $P>|z|$ \\
\hline X1 & .014396 & 0.09 & 0.930 \\
X2 & -9.618387 & -2.74 & 0.006 \\
X3 & -.7188274 & -5.06 & 0.000 \\
\hline
\end{tabular}

From the Table 1 , it was concluded that the independent variables jointly affect the dependent variable. It has evidence by the value of Prob > chi2, which is less than alpha, and it was 0.000 . Judging from the R-squared value of the independent variable in the model, it can explain the dependent variable by $88.63 \%$, while other variables outside the model explain the remaining $11.37 \%$.

Partially, the regional minimum wage has a negative effect on the level of poverty in the Special Region of Yogyakarta. However, it shows that if the regional minimum wage increases by one percent, the poverty rate will decrease by -9.618387 percent in the Special Region of Yogyakarta. The results of this study are under Kaufman and Hotchkiss (1999) research that the increasing regional minimum wage level will increase people's income so that welfare will also increase and impact reducing population poverty. In addition, the research is also in line with research conducted by Riva et al. (2014) and Istifaiyah (2015).

In addition, the human development index variable also has a negative and significant effect on the level of poverty in the Special Region of Yogyakarta. It shows that if the human development index increases by 1 percent, it will reduce poverty by -0.7188274 percent. These results are in line with research conducted by Cholili and Hardjo (2014) states that $\mathrm{HDI}$ has a negative effect on the number of poor people in 33 provinces in Indonesia. Furthermore, this study is also under research conducted by Suliswanto (2010) and Sofilda et al. (2013).

Meanwhile, the unemployment variable proved to have no significant effect on the poverty level. It can be seen from the probability value, which is more than 0.05 . Thus, it is in line with research conducted by Endrayani and Urmila Dewi (2016), which explains that unemployment has no significant effect on poverty in Bali Province.

\section{Conclusion}

From the tests carried out results, it can be concluded that the three independent variables affect the dependent variable. Partially only RMW and HDI have a significant 
effect with a negative correlation. It follows an economic theory where when the RMW level is high, the community will get more wages/income to reduce poverty. The negative HDI coefficient indicates that the better the quality of human resources in an area, the lower the poverty level. It is following the results of previous studies. As indicated by the high HDI score, quality human resources can work in better jobs and higher income levels so that poverty levels can also be reduced. Finally, the unemployment rate has a positive and insignificant effect. It means that the poverty rate in the Special Region of Yogyakarta is not directly affected by the unemployment rate.

DIY has a high poverty rate because the measurement is carried out using the relative poverty method. Prices in DIY tend to be cheaper than in other cities in Indonesia, so the minimum wage is lower than others. In addition, many people can live from their gardens or rice fields, so they do not just rely on income from work to meet their daily needs. Therefore, it makes the poverty rate in the Special Region of Yogyakarta look higher than other provinces despite the high HDI level and low unemployment rate.

The government should increase the regional minimum wage level for each district so that the community can have a higher income and can meet their needs better. In addition, the government is expected to create a new program to increase the Human Development Index. Programs that can be provided include increasing school participation, improving poor nutrition, and improving health services. So it is because the HDI is proven to reduce poverty in the Special Region of Yogyakarta. Although unemployment does not significantly affect, the government must still pay attention to and control the unemployment rate positively correlated to the poverty rate.

\section{References}

Amins, D.B. (2017). Pengaruh tingkat pengangguran terhadap tingkat kemiskinan di kabupaten Berau. ECOBUILD: Economy Bring Ultimate Information All about Development Journal, 1(2), 112-124. Retrieved from

http:/ / download.garuda.ristekdikti.go.id/article.php?article=1005688\&val=15211\&titl e=A\%20PENGARUH $\% 20$ TINGKAT $\% 20$ PENGANGGURAN $\% 20$ TERHADAP \%20TINGKAT\%20KEMISKINAN\%20DI\%20KABUPATEN\%20BERAU

Central Bureau of Statistics (BPS). (2015). Badan Pusat Statistik. Retrieved from BPS Web site: https://www.bps.go.id/

Cholili, F.M., \& Hardjo, M. P. (2014). Analisis pengaruh pengangguran, Produk Domestik Regional Bruto (PDRB), dan Indeks Pembangunan Manusia (IPM) terhadap jumlah penduduk miskin (Studi kasus 33 provinsi di Indonesia). Jumal Ilmiah Mahasiswa FEB Universitas Brawijaya, 2(1). Retrieved from https://jimfeb.ub.ac.id/index.php/jimfeb/article/view/896

Endrayani, N., \& Urmila Dewi, M. (2016). Analisis faktor-faktor yang mempengaruhi tingkat kemiskinan kabupaten/kota di Provinsi Bali. E-Jurnal Ekonomi Dan Bisnis Universitas Udayana, 5(1). Retrieved from https://ojs.unud.ac.id/index.php/EEB/article/view/17369

Istifaiyah, L. (2015). Analisis pengaruh pertumbuhan ekonomi, upah minimum dan pengangguran terbuka terhadap tingkat kemiskinan (Studi kasus Gerbang kertasusila 
tahun 2009-2013). Jurnal Ilmiah Mahasiswa FEB Universitas Brawijaya, 3(2). Retrieved from https://jimfeb.ub.ac.id/index.php/jimfeb/article/view/1949

Itang, I. (2017). Faktor faktor penyebab kemiskinan. Tazkiya, 16(01), 1-30. Retrieved from http://jurnal.uinbanten.ac.id/index.php/tazkiya/article/view/206

Kaufman, B.E., \& Hotchkiss, J.L. (1999). The economics of labor markets. Yogyakarta: BPFE UGM.

Munandar, M., \& Mahmuddin, M. (2019). Pengentasan kemiskinan oleh pemerintah daerah (Studi kasus di Gampong Blang Uyok kecamatan Julok kabupaten Aceh Timur). Jurnal Ilmiah Mahasiswa Fakultas Ilmu Sosial \& Ilmu Politik, 4(3). http://jim.unsyiah.ac.id/FISIP/article/view/11764

Prawoto, N. (2008). Memahami kemiskinan dan strategi penanggulangannya. Jurnal Ekonomi \& Studi Pembangunan, 9(1), 56-68. Retrieved from https://journal.umy.ac.id/index.php/esp/article/view/1530

Probosiwi, R. (2016). Pengangguran dan pengaruhnya terhadap tingkat kemiskinan. Jurnal Penelitian Kesejabteraan Sosial, 15(2), 89-100.

Riva, V.A., Kadir, H., \& Setiawan, D. (2014). Pengaruh tingkat pengangguran dan tingkat upah minimum provinsi terhadap tingkat kemiskinan di Provinsi Riau. Jurnal online mahasiswa Fakultas Ekonomi Universitas Riau, 1(2). 1-15. Retrieved from https://jom.unri.ac.id/index.php/JOMFEKON/article/view/4733

Sofilda, E., Hamzah, M., \& Sholeh, A. (2013). Human development and poverty in Papua Province (An analysis of simultaneous approach on Panel Data Regression). OID $A$ International Journal of Sustainable Development, 6(6), 51-62. Retrieved from https://papers.ssrn.com/sol3/papers.cfm?abstract id $=2382080$

Subandi. (2012). Sistem ekonomi Indonesia. Jakarta: Alfabeta

Sukirno, S. (2006). Makro ekonomi, teori pengantar, 3rd Ed. Jakarta: PT Raja Grafindo Persada

Suliswanto, M. S. W. (2010). Pengaruh Produk Domestik Bruto (PDB) dan Indeks Pembangunan Manusia (IPM) terhadap angka kemiskinan di Indonesia. Jurnal Ekonomi Pembangunan, 8(2), 357. https://doi.org/10.22219/jep.v8i2.3610

Suripto, S., \& Subayil, L. (2020). Pengaruh tingkat pendidikan, pengangguran, pertumbuhan ekonomi dan Indeks Pembangunan Manusia terhadap kemiskinan di D.I. Yogyakarta periode 2010-2017. GROWTH: Jurnal Ilmiah Ekonomi Pembangunan, 1(2), 127-143.

Retrieved from https://stiemmamuju.e-journal.id/GJIEP/article/view/35

Todaro, M.P., \& Smith, S.C. (2006). Pembangunan ekonomi di dunia ketiga. $8^{\text {th }}$ Ed. Jakarta: Erlangga.

Waluyo, D.E. (2007). Ekonomika makro. Revision Ed. Malang: UMM PRESS. 